On the Back Cover:

\title{
A Whitman Tintype?
}

This early tintype was recently added to the collection of Doug Walberg in Bandon, Oregon. The image bears a striking resemblance to Whitman and may be a rare late-1850s photograph of him. Tintypes (sometimes called "ferrographs" or "melainotypes") are photographs produced on black japanned iron; the process was patented by Hamilton L. Smith of Gambier, Ohio, in 1856. Tintypes became extremely popular in 1860 when small tintype medals of the presidential candidates were issued; in the Civil War, tintypes were popular among soldiers for their durability-they were easily produced in the field and safely sent through the mail. Like daguerreotypes, only one picture could be obtained from each exposure (no "negative" was produced from which additional prints could be made), so each tintype is a singular image (see Robert Taft, Photography and the American Scene [New York: Macmillan, 1938], 153-166).

If this is a tintype of Whitman, it would have to be from the late $1850 \mathrm{~s}$, a period from which we have no other photographs of the poet. By the early 1860 s, Whitman's hair and beard were fully gray; the mottled hair and beard in this image would suggest a date somewhere between the 1854 daguerreotypes (numbered 1850s-\#2 and \#3 in the photography issue of WWQR 4 [Fall/ Winter 1986-87] ) and the "shaggy" photo (WWQR 1860s-\#1). The salt-andpepper effect in the hair and beard in this tintype is close to that portrayed in the Schoff engraving of Charles Hine's painting of Whitman, done in 1859 (WWQR 1850s-\#4). The arched eyebrows and the half-hooded eyes that are so striking in this image are familiar Whitman characteristics. Comments about this photo or information pertinent to its identification are welcome and should be sent to $W W Q R$, The University of Iowa, 308 English Philosophy Bldg., Iowa City, IA 52242-1492.

The University of Iowa

ED FoLsOM 